\title{
Business Simulation Training Using Monsoonsim
}

\author{
Rinabi Tanamal, Christian, Yuwono Marta Dinataa), and Evan Tanuwijaya
}

\author{
School of Information Technology, Universitas Ciputra Surabaya, Surabaya, Indonesia \\ a)Corresponding Author: yuwono.dinata@ciputra.ac.id
}

\begin{abstract}
Business simulation training has been conducted by the School of Information Technology, Information Systems Department, Ciputra University, using MonsoonSIM. The aim of this activity is to introduce the concept of Enterprise Resource Planning (ERP) to students through virtual business simulation game. This training was conducted online, due to to Covid-19 pandemic. By using MonsoonSIM software, students can manage a virtual company and learn the company's business processes. Learnings in this training were in the form of material module explanations, simulations, discussions, and evaluations. This program was attended by students from Junior High School and Senior High School. Participants not only play individually to learn from the game experience, but also in a team to compete to be the best virtual company that can dominate the market within a predetermined period of time. By participating in this training, students can manage the operational processes of a virtual company, understand existing resources, and can make a company planning strategy in order to survive and grow.
\end{abstract}

Key words: ERP, MonsoonSIM, Business Simulation

\section{INTRODUCTION}

Seeing the rapid development of technology, marked by the industrial revolution 4.0, where information technology is being intensively integrated into the manufacturing industry. Many companies have used business applications to integrate and accelerate the activities that exist within the company. From these conditions, companies must provide human resources who understand the use of this business application, known as Enterprise Resource Planning (ERP).

ERP system is a business system that has high complexity and supports business processes with integrated real-time information. According to Columbus (Louis Columbus, 2014) at forbes.com, the world's ERP market share shows positive results and still leads the world market share with an estimated transaction value of 25.4 trillion US dollars in 2012. Seeing ERP business opportunities that are getting wider and the lack of knowledge about Enterprise Resource Planning (ERP) among students in Indonesia encourages Ciputra University's School of Information Technology to make a breakthrough to introduce this integrated business system to students, both from Junior High School (SMP) and Senior High School (SMA).

The School of Information Technology conducted a virtual business simulation training using MonsoonSIM software which aims to introduce students to business processes in which the ERP concept is applied. MonsoonSIM is a fun and unique business simulation game (MonsoonSIM, 2021). Some exciting learning methods to understand the ERP concept are in the form of simulation games (Thompson in REFORMASI 2021). This is an exciting learning method compared to case studies or just theoretical explanations.

Simulation games will provide a realistic picture of the activity so that students can play an active role in running the games provided. According to (Mohd Yatim et al in REFORMASI 2021), MonsoonSIM business simulation is a business competition game that educates and trains participants to manage the business with effective decisions within the scope of the simulation. MonsoonSIM is an exciting learning platform because students can play and learn simultaneously with the simulation game. MonsoonSIM is also a unique pedagogical platform that supports experiential learning that helps students explore business concepts with simulation games( Jonathan and Laik in REFORMASI 2021). 
The learning methods used in this training include explanations of the material modules, simulations, discussions, and evaluations. By utilizing this software, students can make business decisions and work together in teams to collaborate to develop their virtual companies. Simulation games can also motivate students through the material provided to create direct feedback that can be accepted by students ( Findawati in Ariyani et al. 2020). This community service activity aims to introduce students to the experience and knowledge of the concept of Enterprise Resource Planning (ERP) in managing the company's business processes. With this activity, students can gain early knowledge about integrated business processes in a company, including Enterprise Resource Planning (ERP).

\section{METHOD}

The implementation method used in this training is to provide a simulation game using the Cloud Base Systems application, which can be accessed through the http://www.monsoonsim.com page. Five people participated in this training, from junior high school and senior high school. This training is carried out online through the Zoom platform and uses MonsoonSIM as a learning medium. The learning method that was used consists of five stages.

The first stage is an explanation of the module from the presenters whom the committee had prepared. In explaining the material, the presenter also carried out a direct simulation using MonsoonSIM on the material module described. The Zoom training material and video modules were also distributed to the participants for them to see and learn more about the material that had been taught. In the second stage, participants did individual simulations to learn from the experience and explore the MonsoonSIM game. For the third stage, participants discussed the game they had played and asked what they still did not understand.

The fourth stage is when they were divided into two teams to compete to be the best virtual company that can dominate the market. And in the last stage, the presenters provided the results from MonsoonSIM to evaluate the performance of the virtual companies they had managed. From the evaluation, the presenters then provided input and direction to the participants so that they understood the mistakes that had been made so that it could be a lesson for the future.

\section{RESULTS}

Business simulation training activities using MonsoonSIM software had been carried out from July $5^{\text {th }}, 2021$ to July $9^{\text {th }}, 2021$ with a duration of four hours per day using 12 modules from MonsoonSIM. The obligation of community service activities is one of the Tridharma of Higher Education (UU No. 12 Tahun 2012 2012). Two presenters facilitated this training and were assisted by two students as facilitators from Ciputra University Surabaya by providing materials and simulations using MonsoonSIM as the learning aid for participants in understanding the business processes of a company. As a result, they could understand the implementation of the ERP concept in the company's business, summarized in a simulation game ,could apply the 12 modules used in the game,

From the training results, using MonsoonSIM as a learning medium could help provide an overview to the participants about the strategies and operational processes of a virtual company's so that their company can survive and grow exponentially. From the results of the survey conducted at the end of the activity, participants felt that this training could be useful in the future, with an average scale of 4.4 out of 5 . Participants also felt that the materials presented were acceptable with an average scale of 4.6 out of 5 . 


\section{DISCUSSION}

The Enterprise Resource Planning (ERP) learning method, which is packaged in the form of a simulation game, is beneficial for students in understanding and applying the concept of ERP. They are also able to play MonsoonSIM using 12 modules which are the implementations of the ERP concept. By using MonsoonSIM, students can manage the operational processes of a virtual company, understand existing resources, and understand business strategies so that the company is able to survive and grow.

By seeing the great interest of students in learning ERP which is packaged in the form of a simulation game, we can say that similar conditions can also be applied to other learning processes in order to attract students' interest in learning. so that the students will not only learn by reading and understanding, but they can also enjoy learning through the simulation game

With the simulation game used in learning, it is hoped that students can enjoy every process in it. If students can enjoy learning, then the ease of students in understanding the material presented will increase so that the function of the teacher in the classroom is as a facilitator, not as a presenter.

\section{CONCLUSIONS AND RECOMMENDATIONS}

With the development of technology that has entered the industrial revolution 4.0, where information technology has penetrated the integrated manufacturing industry. Many companies have used a business application known as Enterprise Resource Planning (ERP) to assist the company's operational activities. Seeing the great ERP business opportunity and the lack of ERP knowledge among students encourages the School of Information Technology, University of Ciputra Surabaya, to hold a business simulation training in which the ERP concept is implemented.

This training uses MonsoonSIM software as a learning medium. MonsoonSIM is a business simulation game that trains participants to explore business concepts by running a virtual company. MonsoonSIM is an exciting learning tool because participants can learn and can also play with the game. By participating in this training, participants can manage business processes, understand existing resources, analyze needs, and plan strategies to develop virtual companies.

Furthermore, it is needed to spread more information about this training in order to meet the expected number of participants. One of the ways is to provide training information to schools that partnered with the university. Therefore, it will create a form of community service that can be useful for a broad audience.

\section{ACKNOWLEDGMENTS}

We thank God for blessing this community service event that went well and smoothly. This community service can be carried out well with the support of (1) Institute for Research and Community Service, Ciputra University Surabaya (2) School of Information Technology, Ciputra University. The author would also like to thank everyone that was involved in this activity so that the "Business Simulation Training Using MonsoonSIM" activity can be carried out properly.

\section{REFERENCES}

Ariyani, Pipin Farida, Titin Fatimah, and Atik Ariesta. 2020. "Simulasi Bisnis Virtual Pada SMK Budi Mulia." Jurnal Abdimas BSI: Jurnal Pengabdian Kepada Masyarakat 3(2):141-47. doi: 10.31294/jabdimas.v3i2.6812.

REFORMASI, BANGKIT AGUNG. 2021. "Minat Mahasiswa Untuk Mengikuti Kompetisi Monsoonsim: Pengembangan Theory Of Planned Behavior."

UU No. 12 Tahun 2012, Pasal 1. Ayat 9. 2012. Undang-Undang Republik Indonesia. Vol. 66.

Louis Columbus. (2014, May 12). https://www.forbes.com/. Retrieved October 15, 2021, from https://www.forbes.com/sites/louiscolumbus/2014/05/12/gartners-erp-market-share-updateshows-the-future-of-cloud-erp-is-now/?sh=7b984041fae9

MonsoonSIM. (2021, April 10). http://www.monsoonsim.com/. Retrieved from http://industri.petra.ac.id/event/view?id=E1254-1615779332 

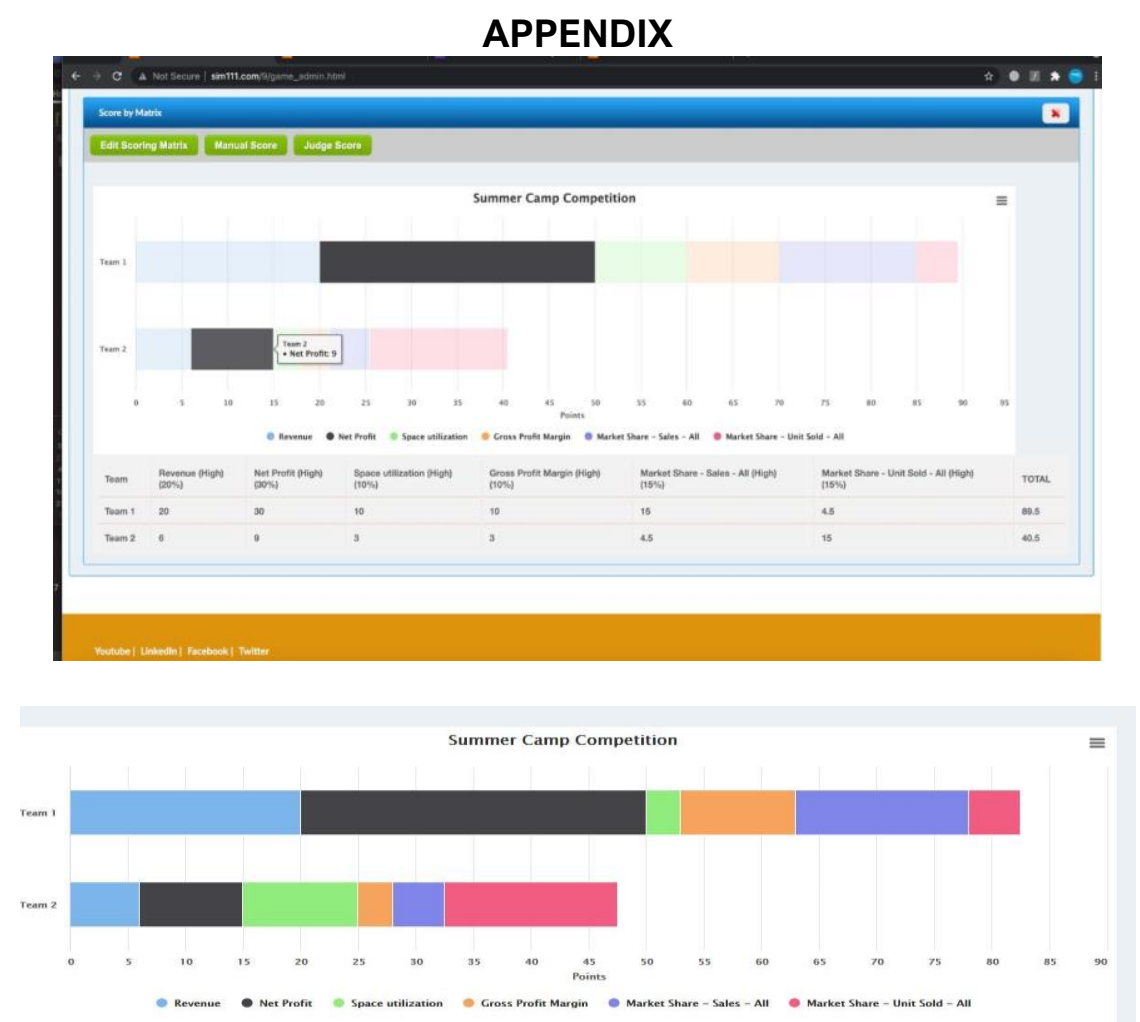

Figure 1. Scoring by matrix MonsoonSIM

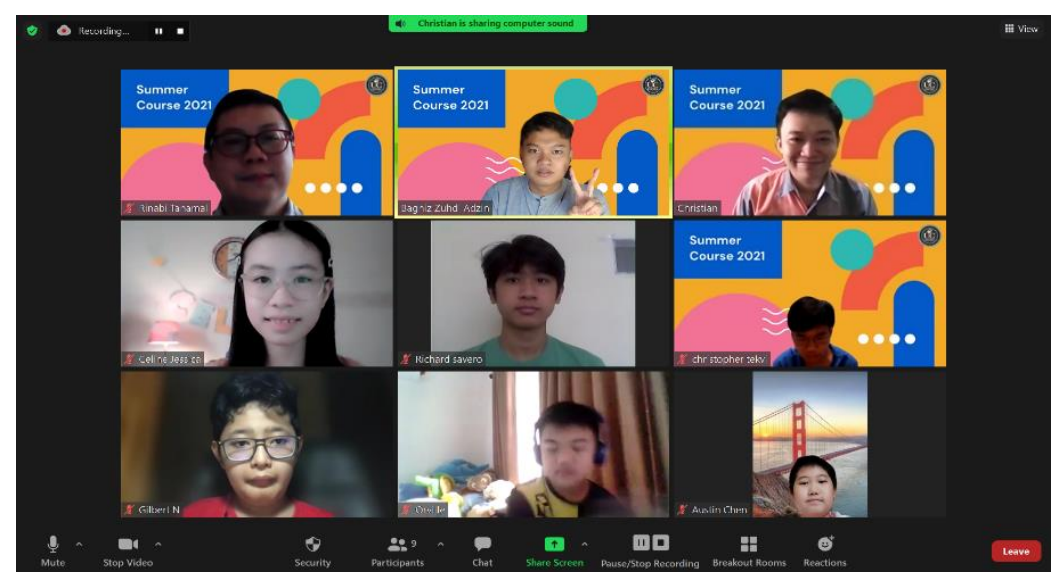

Figure 2. photo of all participants 


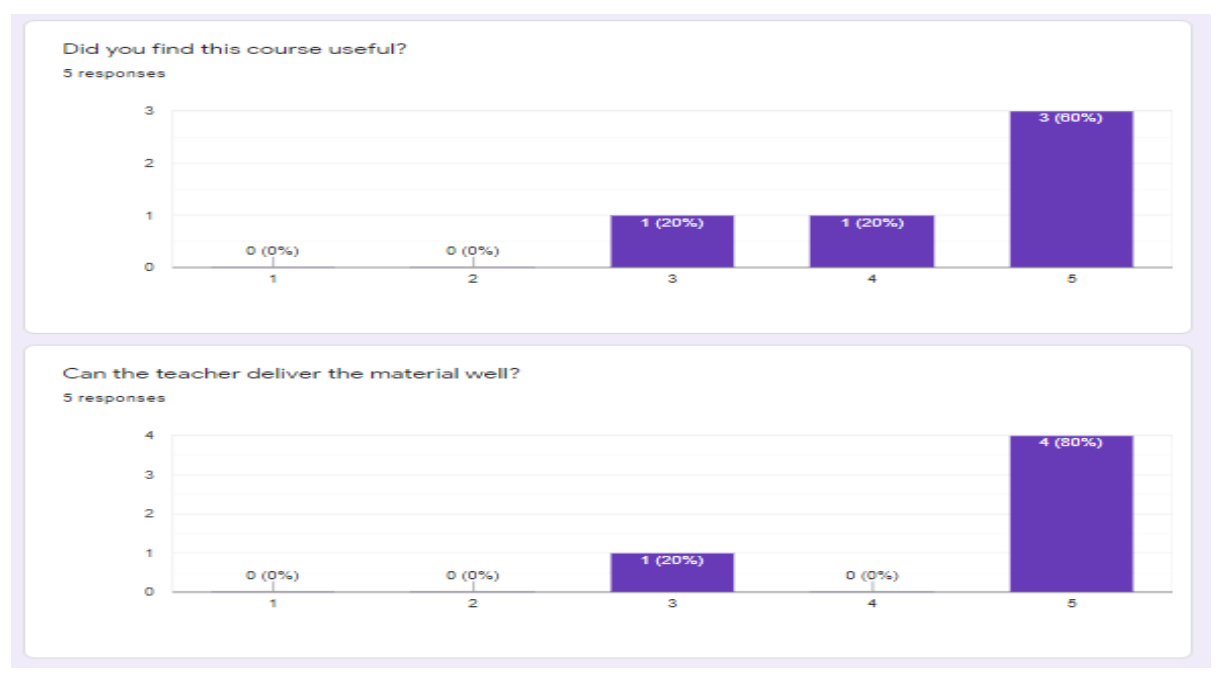

Figure 3. participants survey results 